\title{
PERUBAHAN UPACARA KEMATIAN SAYUR MATUA DALAM ETNIS SIMALUNGUN DI DESA SONDI RAYA
}

\author{
Oleh: \\ Elvera Chrismiseri Purba \\ Pulung Sumantri
}

\begin{abstract}
Research title "Change in Simalungun Ethnic Death Ceremony in Sondi Raya Village". The purpose of writing this thesis is to find out the function of the death ceremony in the ethnic Simalungun, the value contained in the death ceremony, and the changes contained in the process of the death ceremony in the ethnic Simalungun in the village of Sondi Raya. The method used in this study is a historical method that uses written and oral sources, in the form of books and photographs of the Simalungun ethnic death ceremony. Oral sources were obtained through interviews with Raja Parhata (traditional leaders) and religious leaders, as well as laboratory studies using video of death in the village of Sondi Raya. The results obtained are (1) The function of the death ceremony in Simalungun is as a final tribute to the deceased especially to someone who has the title of Sayur Matua. (2) The value contained in the ceremonial death in the ethnic Simalungun namely the value of Sapangahapan is still thick in the Simalungun community, where every misfortune of the surrounding community provides consolation so that families who are grieving do not continue to dissolve in sadness. (3) Changes in the Simalungun death ceremony experienced some of the most striking changes is the gual vegetable matua which was always used during the death ceremony became rare and even changed into modern music, and the size of the porcelain (white cloth) before the size of the porcelain varies depending on the closeness of kinship with deceased person. While now the size is the same for all those who are still close relatives and community mourners in the same village.
\end{abstract}

Keywords: Sayur Matua, Simalungun 


\section{PENDAHULUAN}

Negara Indonesia memiliki keanekaragaman suku bangsa yang tersebar di seluruh bagian tanah air. Masing-masing dari suku tersebut memiliki sejarahnya tersendiri. Selain itu, setiap suku di bagian dari tanah air memiliki keunikan dan nilai tersendiri. Itulah yang membuat bangsa yang mempunyai bendera merah putih ini cukup kaya akan nilai sejarah kebudayaannya.

Keberagaman etnis ini melahirkan kekayaan dan kebudayaan yang tidak ternilai harganya. Hal itu menjadi salah satu kebanggaan negara Indonesia di mata dunia. Sumatera Utara yang menjadi bagian dari Indonesia juga memiliki keanekaragaman suku, salah satunya suku Simalungun. Suku Simalungun merupakan bagian dari Sub-Batak. Sebagai bagian dari suku Batak, suku Simalungun memiliki karakteristik budaya yang unik dan beragam.

Simalungun adalah salah satu kabupaten di Sumatera Utara. Penduduk asli Kabupaten Simalungun adalah etnik Simalungun. Meski sebagian besar menetap di Kabupaten Simalungun, tetapi etnik ini juga menyebar keberbagai wilayah di luar Provinsi Sumatera Utara. Suku Simalungun didasari oleh falsafah "Habonaron Do Bona Bona, Hajungkaton do Sapata" yang berarti segala sesuatu harus berpangkal dari kebenaran. Orang Simalungun yakin bahwa orang yang tidak konsisten menjunjung tinggi falsafah ini akan mendapatkan hal-hal yang tidak baik. Falsafah ini juga berdampak pada pola pikir orang Simalungun yang sangat berhati-hati dalam mengambil keputusan. Suatu keputusan barulah diambil setelah dipikirkan masak-masak, dan sekali ia memutuskannya maka jarang ia menarik keputusannya itu. Hal ini tergambar dalam bunyi, "Parlobei idilat bibir ase marsahap, bijak mosor pinggol asal ulang mosor hata". Ungkapan ini menunjukkan bahwa orang Simalungun bukanlah tipikal manusia yang sembrono atau terburu-buru dalam mengambil dan menentukan sebuah keputusan, seluruhnya harus dipikirkan masakmasak dan keputusan itu adalah tetap, artinya tidak akan pernah berubah lagi. (Purba $2011: 44$ )

Suku Simalungun sangat menghormati dan menjunjung tinggi adatistiadatnya, hal ini yang menyebabkan tercerminnya kepribadian yang mengandung norma dan nilai yang perlu dimiliki oleh setiap manusia dan masyarakatnya. 
Perwujudan dari sikap etnik Simalungun yang sangat menghormati dan menjunjung tinggi kebudayaannya dapat dilihat dalam kehidupan sosial masyarakatnya seharihari serta dalam pelaksanaan setiap upacara adat. Upacara adat-istiadat etnis Simalungun beranekaragam. Mulai dari saat seseorang berada di dalam kandungan ibunya sampai kepada tahap saat meninggalkan dunia (meninggal) mempunyai tradisi adatnya masing-masing. Salah satunya adalah upacara adat kematian.

Bagi etnis Simalungun seseorang yang meninggal akan mengalami perlakuan khusus yang terangkum dalam sebuah upacara adat kematian. Upacara tersebut diklasifikasikan berdasarkan usia, kekayaan dan status sosial orang yang meninggal dunia, yang saling berbeda satu sama lain prosesinya. Kematian dibagi dalam dua bagian besar yaitu: kematian seseorang yang meninggal sebagai duka; dan kematian yang dianggap sebagai suka cita. Upacara adat kematian semakin sarat mendapat perlakuan adat apabila orang yang meninggal: (1). Telah berumah tangga namun anaknya belum ada yang berumah tangga (matei matalpok); (2). Telah memiliki cucu, namun masih ada anaknya yang belum menikah (matei sari matua); dan (3). Telah bercucu dari semua anak laki-laki dan anak perempuannya (matei sayur matua) (Sinaga, 2008:132).

Matei sayur matua menjadi tingkat tertinggi dari klasifikasi upacara bagi masyarakat Batak, karena meninggal pada saat semua anaknya telah berumah tangga dan telah memiliki cucu dari anak-anaknya serta tidak memiliki tanggungan lagi. Masih ada tingkat kematian tertinggi di atasnya, yaitu matei layur matuah, kematian ini terjadi ketika semua anak-anaknya telah berumah tangga, dan telah memberikan tidak hanya cucu, tetapi telah memiliki cicit dari anak laki-laki dan dari anak perempuan. Tingkatan kematian ketiganya dianggap sama sebagai konsep kematian ideal, yakni meninggal pada usia yang lanjut serta tidak memiliki tanggungan anak lagi (Sinaga, $2008: 134)$

Pada saat ini perubahan upacara kematian Simalungun salah satunya dapat dilihat dari tor-tor Toping-Toping yang sudah sangat jarang digunakan dalam upacara kematian di Simalungun. Tarian Toping-toping merupakan tarian yang dilakukan oleh beberapa orang dengan mengenakan kostum berupa topeng dan akan diiringi oleh alat-alat musik tradisional. Adapun penggunaan topeng ini terdiri 
dari tiga macam (1) Topeng Dalahi (Laki-laki); (2) Topeng Daboru(Perempuan); dan (3) Topeng Huda-Huda (topeng yang menyerupai paruh burung enggang, topeng huda-huda ini dipercaya masyarakat Simalungun sebagai pengantar roh orang yang sudah meninggal kepada Tuhan). Namun karena alasan menghemat waktu dan biaya tarian Toping-toping ini sudah jarang dilaksanakan dalam upacara adat kematian Simalungun.

Adapun metode yang digunakan dalam penelitian ini yaitu dengan menggunakan metode sejarah. menurut Gilbert (1957:33) metode sejarah ialah sebagai seperangkat asas dan aturan yang sistematik yang didesain guna membantu secara efektif untuk mengumpulkan sumber-sumber sejarah, menilainya secara kritis yang pada umumnya berbentuk tertulis.

\section{II.PEMBAHASAN}

\section{A. Sejarah Kabupaten Simalungun}

Sebelum kedatangan bangsa Belanda, di Simalungun telah terdapat beberapa kerajaan. Kerajaan-kerajaan tersebut terus mengalami perkembangan sampai kedatangan bangsa Belanda. Ketika itu, Simalungun dibagi kedalam 7 daerah, yang terdiri dari 4 kerajaan dan 3 Partuanan. Kerajaan dipimpin oleh seorang yang bergelar "raja", sedangkan Partuanon dipimpin oleh seorang "tuan". Keempat "kerajaan" tersebut adalah Siantar, Panei, Dolok Silau dan Tanah Jawa. Sedangkan ketiga "Partuanan" yang dimaksud adalah Raya, Purba dan Silimakuta. Kerajaan-kerajaan tersebut diperintah secara swaparaja. Setelah Belanda datang, ketiga Partuanan tersebut dijadikan sebagai kerajaan yang berdiri sendiri secara sah dan dipersatukan dalam Onderafdeeling Simalungun. Dengan Besluit (Surat Keputusan) tanggal 24 April 1906, kemudian diperkuat lagi dengan Besluit tanggal 22 Januari 1908, Raja Siantar Sang Nawaluh dijatuhkan dari tahtanya oleh Pemerintah Hindia Belanda. Sambil menunggu Tuan Kodim akil baliq (dewasa), Kerajaan Siantar sementara dipimpin oleh suatu Dewan Kerajaan yang terdiri dari Tuan Marihat, Tuan Sidamanik dan diketahui oleh Konselir Simalungun. (Sumber : Purba dkk 2011 : 23) 
Setelah dibuangnya Raja Siantar Sang Nawaluh dan Perdana Menterinya Bah Bolak ke Bengkalis Riau, oleh Belanda pada tahun 1906, sudah ratalah kini jalan untuk memaksakan Dewan Kerajaan Siantar yang diketuai Kontelir Belanda itu dan dibentuklah Besluit tanggal 29 Juli 1907 untuk membuat Perjanjian Pendek (Korte Verklaring) tentang takhluknya Siantar kepada Pemerintah Hindia Belanda. Dari isi surat-surat dokumen Belanda dapatlah direka yang tersirat bahwa diturunkannya Raja Sang Nawaluh dari takhta bersama dengan perdana Menterinya Bah Bolak dibuang ke Bengkalis 1906, terutama karena memiliki latar belakang bahwa ia bersama hampir seluruh orang-orang Besar Kerajaan Siantar adalah anti penjajahan Belanda bahwa merembesnya propaganda Islam ke Simalungun khususnya dan Tanah Batak umunya tidaklah disenangi oleh Pemerintah Hindia Belanda. Pada Oktober 1907 oleh Tuan Torialam (Tuan Marihat) dan Tuan Riah Hata (Tuan Sidamanik), melalui Verklaring (surat ikrar), dinyatakan tunduk kepada Belanda. Dalam butir satu Verklaring itu tertulis, "Ten eerste: dat het landschap Siantar een gedeelte uitmaakt van Nederlandsch Indie en derhalve staat onder de heerschappij van Nederland." (Pertama : bahwa wilayah Siantar merupakan bagian dari Hindia Belanda dan karena itu berada di bawah kerajaan Belanda). Masih ditambahkan lagi bahwa akan tetap setia kepada Ratu Belanda dan Gubernur Jenderal. (Sumber Purba dkk 20111:23-24)

Sejak surat Ikrar Torialam dari Marihat dan Riah Hata dari Sidamanik itu, Kerajaan Siantarakhirnya berada dibawah pengawasan Belanda. Belanda kemudian menobatkan putra Sang Naualuh bukan dari permaisuri, yang masih teramat muda, Tuan Radih Kadim, menjadi Raja pengganti. Tuan Radih Kadim yang masih polo situ kemudian diserahkan kepada Belanda. Pendeta Zending Guillaume di Purba pada tahun 1916, Tuan Radih Kadim diubah namanya menjadi Waldemar Tuan Naga Huta dan diakui Belanda sebagai Raja. Setelah Indonesia merdeka, Simalungun terbentuk menjadi salah satu daerah otonom tingkat II di Sumatera Utara. Berdasarkan Undang-Undang No.7 Tahun 1956 terbentuklah Daerah Otonom Kabupaten Simalungun, bersamaan dengan pembentukan 11 daerah otonom lainnya di Indonesia. Berdasarkan Peraturan Pemerintah No. 50 Tahun 1992 dilaksanakanlah pemekaran kecamatan 17 menjadi 21 kecamatan. Kemudian, 
belakangan ini terjadi lagi pemekaran kecamatan sebanyak 10, dengan demikian jumlah seluruh kecamatan di Kabupaten Simalungun saat ini menjadi 31 kecamatan. (Purba dkk 2011:24-25)

\section{B. Upacara Kematian Simalungun}

\section{Tata Upacara Kematian Adat Simalungun}

\begin{tabular}{|c|c|c|c|}
\hline No & $\begin{array}{l}\text { Tahapan } \\
\text { Upacara }\end{array}$ & $\begin{array}{l}\text { Pelaku } \\
\text { Upacara }\end{array}$ & Keterangan \\
\hline 1 & $\begin{array}{l}\text { Padalan } \\
\text { Tugah-tugah }\end{array}$ & $\begin{array}{l}\text { Keluarga yang } \\
\text { berduka }\end{array}$ & $\begin{array}{l}\text { Keluarga inti menyampaikan beritaduka } \\
\text { cita kepada Tondong (pamandari yang } \\
\text { meninggal) }\end{array}$ \\
\hline 2 & $\begin{array}{l}\text { Riah Tongah } \\
\text { Jabu }\end{array}$ & $\begin{array}{l}\text { Keluarga yang } \\
\text { berduka, pihak } \\
\text { tondong, } \\
\text { Masyarakat } \\
\text { sekampung } \\
\text { (STM) }\end{array}$ & $\begin{array}{l}\text { Keluarga yang berduka bermusyawarah } \\
\text { dengan tondong dan masyarakat } \\
\text { sekampung/ Serikat Tolong Menolong } \\
\text { (STM) tentang penentuan waktu } \\
\text { penguburan, dan waktu dimulainya acara } \\
\text { adat }\end{array}$ \\
\hline 3 & Tampei Porsa & Pihak tondong & $\begin{array}{l}\text { Pihak tondong memakaikan tampei } \\
\text { porsa (kainputih yang diikat dikepala) } \\
\text { kepada keluarga yang berduka }\end{array}$ \\
\hline 4 & $\begin{array}{l}\text { Pahata } \\
\text { Gonrang }\end{array}$ & $\begin{array}{l}\text { Cucu laki-laki, } \\
\text { Cucu } \\
\text { perempuan } \\
\text { (sulung), } \\
\text { keluarga inti, } \\
\text { pihak tondong, } \\
\text { dan Panggual }\end{array}$ & $\begin{array}{l}\text { Pemukulang onrang pertama dilakukan } \\
\text { oleh cucu laki-laki dan cucu perempuan } \\
\text { paling sulung, saat itu juga panggual } \\
\text { disuguhkan ayam sembelihan (dayok } \\
\text { nabinatur). }\end{array}$ \\
\hline \multirow[t]{2}{*}{5} & Mandingguri & Keluarga inti & Acara keluarga inti \\
\hline & $\begin{array}{l}\text { a. } \\
\text { Mamungkah } \\
\text { Gonrang }\end{array}$ & Panggual & $\begin{array}{l}\text { Panggual membuka acara dengan } \\
\text { sebutan mamungkah gonrang, dan } \\
\text { memainkan dua gual sebagai tanda } \\
\text { bahwa acara telah dibuka. Setelah itu } \\
\text { pihak keluarga inti menari pada tahapan } \\
\text { yang disebut mandingguri. }\end{array}$ \\
\hline
\end{tabular}




\begin{tabular}{|c|c|c|c|}
\hline & $\begin{array}{l}\text { b. } \\
\text { Mandingguri } \\
\text { Hasuhutan } \\
\text { Bolon }\end{array}$ & $\begin{array}{l}\text { Tondong } \\
\text { (Hasuhutan } \\
\text { Bolon) }\end{array}$ & $\begin{array}{l}\text { Pihak tondong diperbolehkan menari dan } \\
\text { meminta gual yang diinginkan. }\end{array}$ \\
\hline 6 & $\begin{array}{l}\text { Mangoromin } \\
\text { a Matei }\end{array}$ & $\begin{array}{l}\text { Keluarga yang } \\
\text { berduka, Pihak } \\
\text { Tondong } \\
\text { Masyarakat } \\
\text { sekampung } \\
\text { (STM) }\end{array}$ & $\begin{array}{l}\text { Acara mangoromi namatei ini dilakukan } \\
\text { dengan tujuan menemani keluarga yang } \\
\text { berduka menjaga jenazah sebelum } \\
\text { dikebumikan }\end{array}$ \\
\hline 7 & $\begin{array}{l}\text { Pamasuk } \\
\text { Hurumah- } \\
\text { rumah }\end{array}$ & $\begin{array}{l}\text { Keluarga yang } \\
\text { berduka,Pihak } \\
\text { Tondong }\end{array}$ & $\begin{array}{l}\text { Proses memasukkan jenazah ke dalam } \\
\text { peti mati (rumah-rumah) yang dilakukan } \\
\text { oleh keluarga yang berduka dan pihak } \\
\text { tondong. }\end{array}$ \\
\hline 8 & Pangiligion & $\begin{array}{l}\text { Keluarga yang } \\
\text { berduka,Pihak } \\
\text { Tondong }\end{array}$ & $\begin{array}{l}\text { Proses pemberian adat oleh pihak } \\
\text { tondong yang pada kedatangannya } \\
\text { membawakan Tombuan Sayur Matua } \\
\text { serta menghibur keluarga yang berduka } \\
\text { karena ditinggal oleh orangtua tersebut. }\end{array}$ \\
\hline 9 & $\begin{array}{l}\text { Hiou } \\
\text { Parpudidan } \\
\text { Manangkih } \\
\text { Gonrang }\end{array}$ & $\begin{array}{l}\text { Keluarga yang } \\
\text { berduka, Pihak } \\
\text { Tondong,da } \\
\text { Panggual }\end{array}$ & $\begin{array}{l}\text { Proses acara ini dilakukan di halaman } \\
\text { rumah, pemberian cinderamata terakhir } \\
\text { oleh pihak tondong yaitu memberikan } \\
\text { Hiou Parpudi yang diberikan tondong } \\
\text { kepada yang meninggal. Setelah acara } \\
\text { pemberian Hiou Parpudi itu selesai } \\
\text { maka dilanjutkan acara manangkih } \\
\text { Gonrang (Penutup gendang). }\end{array}$ \\
\hline 10 & Paragendaon & $\begin{array}{l}\text { Keluarga yang } \\
\text { berduka, Pihak } \\
\text { tondong, } \\
\text { Panggual, dan } \\
\text { Tokoh Agama }\end{array}$ & $\begin{array}{l}\text { Pemberangkatan jenazah dan acara } \\
\text { diambil alih olehTokoh Agama. }\end{array}$ \\
\hline
\end{tabular}




\section{Fungsi Upacara Kematian}

Dalam masyarakat Simalungun jika ada seorang yang sudah bergelar sayur matua meninggal maka terlebih dahulu diberitahukan kepada kerabat dekatnya, kemudian barulah kepada masyarakat setempat, biasanya hal itu ditandai dengan bunyi lonceng digereja, lonceng itu dibunyikan sesuai dengan jumlah umur yang meninggal. Itulah salah satu fungsi dari upacara kematian, bahwa semua orang mengetahui bahwa yang bersangkutan sudah meninggal.

Fungsi lain dari upacara kematian sayur matua Simalungun ialah bermusyarawah antara keluarga yang berdukacita dengan masyarakat setempat (STM) tentang dimana jenazah dikebumikan dan kapan waktunya. Bukan tidak mungkin bahwa sebelum yang bersangkutan meninggal dia sudah meminta terlebih dahulu dimana dia akan dikebumikan seperti dibelakang rumah, diladang, maupun dikampung kelahirannya. Oleh karena itu penting bagi keluarga bermusyarwah tentang mungkin tidaknya jenazah tersebut dikebumikan di kampung halamannya, bisa jadi jarak antara kampung dan rumah nya sangat jauh sehingga memakan waktu yang lama, maka perlu dicari jalan keluar lain tempat dikebumikannya jenazah tersebut.

Memberikan hiou na parpudi juga merupakan salah satu fungsi upacara kematian sayur matua dimana tradisi ini adalah pemberian hiou kepada yang meninggal dengan tujuan untuk member penghormatan terakhir kepada yang meninggal semasa hidupnya. Hiou ini diberikan oleh pihak tondong yang akan disambut oleh anak-anak dari yang meninggal tersebut.

\section{Perbandingan Pelaksanaan Upacara Adat Kematian Dulu dan Sekarang}

\begin{tabular}{|l|l|l|l|}
\hline No & $\begin{array}{l}\text { Jenis Upacara / } \\
\text { makna }\end{array}$ & Pelaksanaan Dahulu & Pelaksanaan Sekarang \\
\hline 1 & $\begin{array}{l}\text { Gual Sayur } \\
\text { Matua }\end{array}$ & $\begin{array}{l}\text { Selama upacara adat } \\
\text { berlangsung sampai } \\
\text { berakhir gual yang } \\
\text { dibunyikan }\end{array}$ & $\begin{array}{l}\text {-Semakin Jarang } \\
\text {-Berubah menjadi } \\
\text { musik modern }\end{array}$ \\
\hline 2 & Makan Bersama & $\begin{array}{l}\text { Kematian yang memiliki } \\
\text { cucu }\end{array}$ & $\begin{array}{l}\text { Pada setiap tingkatan } \\
\text { status kematian }\end{array}$ \\
\hline
\end{tabular}




\begin{tabular}{|c|c|c|c|}
\hline 3 & $\begin{array}{l}\text { Memasukkan } \\
\text { jenazah kedalam } \\
\text { peti mati }\end{array}$ & $\begin{array}{l}\text { Jenazah dimasukkan } \\
\text { kedalam peti pada sore } \\
\text { hari dihalaman rumah } \\
\text { dihari penguburan }\end{array}$ & $\begin{array}{l}\text { Jenazah dimasukkan } \\
\text { kedalam peti pada pagi } \\
\text { hari. }\end{array}$ \\
\hline 4 & $\begin{array}{l}\text { Lamanya Waktu } \\
\text { Penguburan }\end{array}$ & 7 hari & 3-4 hari \\
\hline 5 & $\begin{array}{l}\text { Ukuran Porsa } \\
\text { (KainPutih) }\end{array}$ & $\begin{array}{l}\text { Ukuran berbeda tergantung } \\
\text { kepada kedekatan dengan } \\
\text { orang yang meninggal }\end{array}$ & $\begin{array}{l}\text { Ukuran porsa sama } \\
\text { semua }\end{array}$ \\
\hline 6 & $\begin{array}{l}\text { Pelaksanaan } \\
\text { tarian toping- } \\
\text { toping }\end{array}$ & Ada & $\begin{array}{l}\text {-Jarang (hanya } \\
\text { keluarga yang kaya } \\
\text { yang mampu } \\
\text { mengadakan tarian } \\
\text { toping-toping }\end{array}$ \\
\hline 7 & Mansaburhonduit & $\begin{array}{l}\text { Hanya untuk keluarga } \\
\text { yang berdukacita }\end{array}$ & $\begin{array}{l}\text { Masyarakat umum } \\
\text { semakin banyak yang } \\
\text { ikut }\end{array}$ \\
\hline 8 & Manaburgaram & Ada & Semakin jarang \\
\hline
\end{tabular}

Upacara adat kematian etnis Simalungun memang memiliki perubahan yang disebabkan oleh perkembangan jaman dan kemajuan teknologi.

\section{PENUTUP}

Upacara kematian Sayur matua merupakan suatu gelar yang diberikan kepada seseorang yang sudah meninggal jika semua anaknya sudah menikah dan telah mempunyai cucu dari anak laki-laki dan perempuannya. Sayur matua merupakan tingkat kematian yang didambakan setiap masyarakat Simalungun karena dapat dikatakan bahwa tanggungjawabnya didunia ini sudah selesai mendidik anak-anaknya sampai semuanya berkeluarga.

Bagi masyarakat Simalungun pelaksanaan upacara kematian sudah menjadi tradisi turun temurun yang dilakukan bagi kerabat yang sudah meninggal apalagi sudah berada di fase sayur matua, sebagai penghormatan terakhir kepadanya atas jasa-jasa, kebaikan dan kerja kerasnya semasa hidupnya didunia serta ucapan syukur kepada sang pencipta karena telah memberikan umur yang panjang semasa hidupnya.

Seiring berkembangnya jaman, upacara kematian di Simalungun mengalami beberapa perubahan yang terjadi terkhusus kepada upacara kematian 
sayur matua, dimana perubahan yang paling dominan adalah pada ukuran porsa (kain putih) dan pahata gonrang/gualnya.

\section{REFERENSI}

Agustono, dkk. (2012). Sejarah Etnis Simalungun. Medan

Daliman, A. (2012). Metode Penelitian Sejarah. Yogyakarta : Ombak

Firmando, Harisan. (2018). Perubahan Sosial Dalam Upacara Adat Kematian Pada Etnis batak Toba di Kota Medan. Thesis-Sosiologi Universitas Sumatera Utara

Geertz, Clifford. (1992). Kebudayaan \& Agama. Yogyakarta : Kanisius

Koentjaraningrat. 1974. Kebudayaan Mentalitet dan Pembangunan. Jakarta : Gramedia

Koentjaraningrat. (1981). Pengantar Ilmu Antropologi. Jakarta : Rineka Cipta

Koentjaraningrat. (2012). Pengantar Ilmu Antropologi. Jakarta : PT Rineka Cipta

Manurung, M Fretdy. (2013). Makna Kerbau (Horbo) Pada Masyarakat Batak Toba Dalam Upacara Kematian Saur Matua Di Kecamatan Simanindo Kabupaten Samosir. Skripsi-Pendidikan Sejarah UNIMED

Moleong, Lexy. (2012). Metodologi Penelitian Kualitatif. Bandung : PT Remaja Rosdaklarya

Purba, Fransiskus dkk. (2011). Mengenal Kabupaten Simalungun. Medan : CV.Mitra

Rudolf Purba, JE. Saragih dkk. (2012). Peradaban Simalungun. Pematangsiantar : Komite Penerbit Buku-Buku Simalungun

Sinaga, Richard. (2013). Meninggal Adat Dalihan NaTolu. Jakarta : Dian Utama

Sinaga, Salmon. (2008). Adat ni Simalungun. Pematang Siantar : Presidium PMS

Sitanggang, Radesman. 2014. Orientasi Nilai Budaya Folklore Etnik Simalungun. Medan : L-SAPA

Sugiyono. (2015). Metode Penelitian. Bandung : Alfabeta.

Syani, Abdul. (1995). Sosiologi dan Perubahan Masyarakat. Lampung : Pustaka Jaya 